\title{
SOSIAL MEDIA SARANA PROMOSI PADA PEDAGANG PAKAIAN DI PASAR SUDIMAMPIR BANJARMASIN
}

\author{
Ariyadi \\ Dosen FAI Universitas Muhammadiyah Palangka Raya \\ ariyadialbanjari@gmail.com \\ Maria Ulfah \\ Mahasiswa MES Pascasarjana IAIN Palangka Raya \\ mariaulfahmawar@gmail.com
}

Received : 2019-04-02 ; Accepted :2019-07-06 ; Published : 2019-04-24

\begin{abstract}
Abstrak:The rise of promotions and buying-selling through internet where social media has become one of the media, it has many positive impacts, such as buyingselling transactions have become easier. Meanwhile, it has negative impacts too, such as fraud and others, this makes researchers interested in researching how clothing traders on the Sudimampir market, Banjarmasin utilizes media as a promotion in order to be able to compete and increase their sales. This research aims to find out how the use of social media in clothing in Sudimampir market, as well as the obstacles that faced when using social media as a means of promotion. The researcher used field research, which is descriptive qualitative by conducting in-depth interviews and then the results can be summarized. The informants in this study were 15 people, all of whom were clothing traders who were selling in the Sudimampir market.

The results of this study indicate that the use of social media as a promotion of clothing Sudimampir market using several social media such as: WA (Whatsapp), BBM (Blackberry Messenger), FB (Facebook). Those social media used as a means for ordering, Facebook and Instagram used for uploading photos of the items they sell. Those social media give a positive impact, namely their sales have increased which is in accordance with the function of social media in trading, which can increase sales.
\end{abstract}

Keywords: social media, traders, Sudimampir

Manusia adalah makhluk hidup yang saling berhubungan dengan lingkungan masyarakat dan bekerja sama dengan orang lain dalam rangka pemenuhan kebutuhan yang beraneka ragam (Suhrawardi, 2000:3). Islam sangat menganjurkan pemiliknya untuk berusaha termasuk melakukan kegiatan-kegiatan bisnis. Dalam kegiatan bisnis, seseorang dapat menentukan sesuatu dengan sebaik-baiknya agar dapat menghasilkan sesuatu yang diharapkan (Antonio, 2001:191) Berbisnis merupakan kegiatan ekonomi yang pada prinsipnya bertujuan mendapatkan keuntungan sebagai hasil akhir. Bisnis itu sendiri memiliki berbagai macam bentuk yaitu, pertanian, perkebunan, peternakan dan perdagangan, baik 
barang ataupun jasa. Yang mana peran teknologi yang paling banyak berpengaruh dalam melakukan kegiatan bisnis.

Perdagangan dalam era globalisasi yang di iringi dengan perkembangan IPTEK yang semakin canggih, seperti penyebaran informasi serta akses komunikasi melalui media sosial begitu cepat dan efisien. Hal tersebut baik secara langsung maupun tidak langsung berdampak terhadap masyarakat. Baik itu berdampak positif maupun dampak negative. Dampaknya pun tidak terbatas pada kalangan tertentu saja, namun telah meluas ke semua kalangan baik kalangan terpelajar maupun bukan terpelajar.

Akibat progres teknologi, akan terjadi kejutan-kejutan di masa depan yang melahirkan revolusi baru. Kehidupan manusia atau kegiatan ekonomi dunia tidak lagi dipimpin oleh industri, namum teknologi informasi akan muncul sebagai penggerak kehidupan dan kegiatan bisnis.(Sayuti, 2015:81)

Dalam kegiatan bisnis tidak lepas dari yang namanya pemasaran. Pemasaran adalah proses mengkonsentrasikan berbagai sumber daya dan sasaran dari sebuah organisasi pada kesempatan dan kebutuhan lingkungan. Dalam tiga dekade terakhir konsep pemasaran telah berubah secara dramatis, konsep pemasaran telah berkembang dari konsep pemasaran semula, yang memfokuskan pemasaran pada produk dan pada membuat produk yang lebih baik, sedangkan konsep baru dari pemasaran yang muncul kira-kira tahun 1960, mengalihkan fokus pemasaran dari produk kepelanggan. Tetapi cara mencapainya menjadi lebih luas termasuk seluruh bauran pemasaran (marketing mix), atau "empat P" seperti yang dikenal secara luas: product, price, promotion, dan place atau produk, harga, promosi, dan saluran distribusi (Keegan, 1996:167).

Dalam strategi pemasaran ada namanya "empat P" yang mana salah satu dari 4P tersebut ialah promotion atau promosi. Promosi mengacu pada setiap insentif yang digunakan oleh produsen untuk memicu transaksi (pedagang besar dan ritel) atau konsumen untuk membeli suatu merek serta mendorong tenaga penjualan untuk secara agresif menjualnya (Shimp, 2003:111) Dalam penggunaannya promosi dapat dilakukan dengan berbagai media seperti membagikan pamflet dan brosur, membuat iklan di majalah dan koran yang biasa disebut dengan media cetak, promosi menggunakan media masa seperti iklan di televisi atau radio, dan yang saat ini sedang ramai dikalangan masyarakat apalagi yang memiliki usaha yaitu promosi menggunakan media sosial seperti Facebook, Instagram, BBM, WA dan lain-lain.

Media sosial merupakan alat komunikasi, sepereti telepon dan email, yang mendukung tujuan fugsi bisnis penting, termasuk didalamnya hubungan masyarakat, pemasaran, pembangkitan minat pelanggan, layanan pelanggan, dan riset pasar. Beberapa di antara penggunaan paling baik untuk aktivitas media sosial adalah untuk mendukung fungsi-fungsi bisnis ini, setiap fungsi bisnis tersebut sudah memiliki objektif dan targetnya, di mana anda bisa memasukkan aktivitas medai sosial ke dalamnya (Blanchard, 2015:19).

Media sosial banyak digunakan dikalangan masyarakat termasuk para pedagang baik itu pedagang elektonik, kuliner, pakaian, dll. Para pedagang tersebut menggunakan media sosial untuk mepromosikan produk mereka agar dapat bertahan dalam persaingan pasar. Salah satu pasar yang ada di kota 
Banjarmasin adalah pasar Sudimampir yang sudah dikenal oleh masyarakat Banjarmasin maupun luar kota Banjarmasin. Pasar Sudimampir terletak di pusat Kota Banjarmasin, tepatnya di samping Jembatan Sudimampir, Jln. Ujung Murung, Kertak Baru Ulu, Banjarmasin Tengah, Kota Banjarmasin. Pasar ini selain menjaul eceran, merupakan pusat grosir terbesar di Banjarmasin, sudah sejak lama ada dan dikenal sebagai pasar tempat para pedagang busana berbelanja. Mereka kemudian menjualnya lagi ke berbagai daerah, baik dari Kalimantan Selatan sendiri, hingga Kalimantan Tengah dan Kalimantan Timur.

Seiring dengan manfaat yang ditimbulkan melalui media sosial terlebih dalam melakukan promosi, media sosial juga menimbulkan dampak negatif seperti seringnya terjadi penipuan melalu media sosial, penjualan melalu media sosial sering sekali mendapat komplain dari pelanggan karena ketidaksesuaian barang yang sudah dipesan sehingga kurangnya kepercayaan untuk membeli barang melalui media sosial. Banyaknya dampak positif dan negatif yang ditimbulkan oleh media sosisal penulis ingin menegetahui lebih mendalam mengenai pemanfaatan dan apa saja yang menjadi hambatan atau kendala untuk menggunkan media sosial sebagai salah satu cara untuk mempromosikan barang atau usaha mereka tersebut.

\section{METODE PENELITIAN}

Penelitian yang dilaksanakan ini adalah penelitian lapangan (field research) yaitu metode menemukan secara spesifik dan realitas(Subagyo, 1999:28). Tentang Pemanfaatan Media Sosial Sebagai Sarana Promosi pada Pedagang Pakaian di Pasar Sudimampir Banjarmasin. Pendekatan penelitian ini bersifat kualitatif, dimana data-data yang dikumpulkan data-data kualitatif. Pendekatan kualitatif adalah prosedur penelitian yang menghasilkan data diskriptif berupa kata-kata tertulis atau lisan dari orang-orang atau prilaku yang diamati (Rahmadi, 2011:13). Lokasi penelitian ini adalah Pasar Sudimampir terletak di pusat Kota Banjarmasin, tepatnya di samping Jembatan Sudimampir, Jln. Pangeran Antasari, Banjarmasin. Adapun alasan memilih lokasi ini karena Pasar Sudimampir merupakan pusat grosir terbesar di Banjarmasin, sudah sejak lama ada dan dikenal sebagai pasar tempat para pedagang busana melakukan transaksi jual beli.

\section{PEMBAHASAN}

Para ahli telah menegemukakan beberapa definisi tentang pemasaran yang kelihatan agak berbeda meskipun sebenarnya sama. Perbedaan-perbedaan ini disebabkan karena mereka meninjau pemasaran dari segi yang berbeda-beda, ada yang lebih menitikberatkan pada segi fungsi, segi barang, segi kelembagaan, segi manajemennya, dan ada pula yang menitikberatkan dari semua segi tersebut sebagai suatu sistem. Beberapa di antara para ahli tersebut (Philip Kotler), pertukaran merupakan titik pusat kegiatan pemasaran dimana seseorang berusaha menawarkan sejumlah nilai kepada orang lain. Dengan adanya pertukaran, berbagai macam kelompok sosial seperti individu-individu, kelompok kecil, organisasi, dan kelompok masyarakat lain dapat terpenuhi. Kita telah menegetahui 
bahwa di dalam masyarakat terdapat berbagai macam kelompok yang ingin memenuhi kebutuhannya untuk maksud tersebut, mereka harus melakukan suatu usaha, sehingga satu dengan yang lain saling melayani. Kotler mengemukakan difinisi pemasaran sebagai berikut, Pemasaran adalah kegiatan manusia yang diarahkan pada usaha untuk memuaskan keinginan dan kebutuhan malaui proses pertukaran.

Menurut difinisi tersebut, mula-mula manusia harus menemukan kebutuhannya dulu, baru kemudian berusaha untuk memenuhinya dengan cara mengadakan hubungan, dapat pula dikatakan bahwa kegiatan pemasaran itu diciptakan oleh pembeli dan penjual, kedua belah pihak sama-sama ingin mencari kepuasan (Swastha, 1999:5-6)

\section{1) Strategi Pemasaran}

Strategi pemasaran merupakan ujung tombak untuk meraih konsumen sebanyak-banyaknya. Disamping itu, tujuan startegi pemasaran juga digunakan untuk menjatuhkan melawan, atau menghadapi serangan pesaing yang ada dan yang akan masuk. "Strategy is the game plan management is using to stake out a market position attract please customers, compete successfully, cunduct operation, and achieve organization abjectives" (Thompson, 2004:3). ("Strategi adalah pengelolaan rencana dengan memanfaatkan posisi pasar untuk menarik pelanggan, bersaing dengan sehat, dan melakukan operasi untuk mencapai tujuan organisasi").

Strategi adalah langkah-langkah yang harus dijalankan oleh suatu perusahaan untuk mencapai tujuan. Kadang-kadang langkah yang harus dihadapi terjal dan berliku-liku, namun ada pula langkah yang relatif mudah. Disamping itu, banyak rintangan atau cobaan yang dihadapi untuk mencapai tujuan. Oleh karena itu, setiap langkah harus dijalankan secara hati-hati dan terarah (Kasmir, 2010:171). Pengertian pemasaran seperti yang dikemukakan oleh ahli pemasaran dunia yaitu Philip Kotler adalah:

"suatu proses sosial dan manajerial dengan mana individu dan kelompok memperoleh apa yang mereka butuhkan dan inginkan dengan cara menciptakan serta mempertukarkan produk dan nilai dengan pihak lain" (Kasmir, 2010:171).

Strategi pemasaran sudah sangat dikenal luas, bauran pemasaran pada strategi, bauran pemasaran atau lebih dikenal dengan nama marketing mix strategy.

Pelaksanaan strategi ini dibagi kedalam:

1. Strategi lokasi dan distribusi

2. Strategi promosi

3. Strategi produk

4. Strategi harga

Masing-masing strategi berkaitan erat satu sama lain. Setiap salah satu strategi yang akan ditetapkan harus mempertimbangkan strategi lainnya. Akan sangat berbahaya jika pelaksanaan strategi tidak dilakukan dengan matang dan tidak berkaitan satu sama lain. (Kasmir, 2010:171). 


\section{2) Strategi Promosi}

"Promotion is communicating information between seller and potential buyer or others in the channel to influence attittudes and behavior", (Perreault \&McCharthy, 2002:378).

Promosi merupakan salah satu kegiatan marketing mix. Kegiatan ini sama pentingnya dengan ketiga kegiatan yang lain, baik produksi, harga, maupun distribusi. Dalam kegiatan ini setiap perusahaan berusaha mempromosikan seluruh produk atau jasa yang dimilikinya, baik langsung maupun tidak langsung. Tanpa promosi pelanggan tidak dapat mengenal produk atau jasa yang ditawarkan. Oleh karena itu, promosi merupakan sarana yang paling ampuh untuk menarik dan mempertahankan konsumen. Salah satu tujuan promosi adalah menginformasikan segala jenis produk atau jasa yang ditawarkan dan berusaha menarik calon konsumen yang baru.

Startegi promosi adalah perencanaan, implementasi, dan pengendalian komunikasi dari suatu organisasi kepada konsumen dan sasarannya. Fungsi promosi dalam bauran pemasaran adalah untuk mencapai berbagai tujuan komunikasi dengan setiap konsumen (Cravens, 2002:77). Promosi penjualan, sebagai unsur utama dalam kampanye pemasaran, adalah berbagai kumpulan alatalat insentif yang sebagian besar berjangka pendek, yang dirancang untuk merangsang pembelian produk atau jasa tertentu dengan lebih cepat dan lebih besar oleh konsumen atau pedagang. (Kotler \& Keller, 2008:265). Jadi, promosi merupakan salah satu aspek yang penting dalam manajemen pemasaran, dan sering dikatakan sebagai "proses berlanjut". Ini disebabkan karena promosi dapat menimbulkan rangkaian kegiatan selanjutnya dari perusahaan (Swastha, 1999:237).

\section{3) Strategi Pemasaran Syariah}

Nilai transaksi yang terpenting dalam bisnis adalah al-amanah (kejujuran). Ia merupakan puncak moralitas iman dan karakteristik yang paling menonjol dari orang yang beriman. Bahkan kejujuran merupakan karakteristik dari para Nabi. Tanpa kejujuran, kehidupan agama tidak akan berdiri tegak dan kehidupan dunia tidak akan berjalan baik.

Ada empat hal yang menjadi key success factors (KSF) dalam mengelola strategi pemasaran syariah, yaitu:

a. Shiddiq (benar dan jujur),

b. Amanah (terpercaya, kredibel),

c. Fathanah (cerdas),

d. Tablig (komunikatif). (Swastha, 1999:237)

\section{4) Bauran promosi}

Promosi merupakan elemen bauran pemasaran yang menunjang strategi bauran pemasaran lainnya. Tanpa promosi, produk tidak akan dikenal oleh konsuman. Komponen-komponen promosi terdiri dari periklanan, penjualan peribadi, publisitas dan promosi penjualan (Abdullah, 2011:135). Kombinasi yang 
baik dari variabel-variabel periklanan, personal selling, dan alat promosi yang lain, yang semuanya direncanakan untuk mencapai tujuan program penjualan (Swastha, 1999:238-239).

Ada empat macam sarana promosi yang dapat digunakan oleh setiap perusahaan dalam mempromosikan produknya, baik barang maupun jasa. Keempat macam sarana promosi yang dapat digunakan adalah:

1. Periklanan (advertising);

Periklanan dilakukan dengan mengeluarkan sejumlah biaya, ini berbeda dengan publisitas yang disiarkan tanpa mengeluarkan biaya. Jadi , periklanan juga merupakan alat yang digunakan oleh pembeli dan penjual, serta setiap orang termasuk lembaga non-laba. Atau dengan kata lain, periklanan dapat dipandang sebagai kegiatan penawaran kepada suatu kelompok masyarakat baik secara lisan ataupun dengan penglihatan (berupa berita) tentang suatu, jasa atau ide.

2. Promosi penjualan (sales promotion product);

Meskipun menggunakan istilah "promosi" tetapi pengertian "promosi penjualan" itu berbeda dengan "promosi" itu sendiri. Promosi merupakan istilah yang menggambarkan suatu bidang yang luas, sedangkan promosi penjualan hanya merupakan satu bagian saja dari promosi.

3. Publisitas (publicity);

Publisitas merupakan pelengkap yang efektif bagi alat promosi yang lain seprti periklanan, personal selling, dan promosi penjualan. Biasanya, media bersedia mempublisitaskan suatu cerita apabila mateinya dirasa cukup menarik atau patut dijadikan berita.

4. Penjualan pribadi (Personal Selling).

Personal selling merupakan komunikasi orang secara individual. Lain halnya denga periklanan dan kegiatan promosi lain yang komunikasinya bersifat masal dan tidak pribadi. Dalam operasinnya, personal selling lebih fleksibel dibandingkan dengan yang lain. Ini disebabkan karena tenagatenaga penjualan tersebut dapat secara langsung mengetahui keinginan, motif, dan perilaku konsumen dan sekaligus dapat melihat reaksi konsumen sehingga mereka dapat melakukan penyesuaian seperlunya (Swastha, 1999:238-239).

\section{5) Pemasaran Online}

Pemasaran online (online marketing) dilakukan melalui sistem komputer online, yang menghubungkan pelanggan dengan penjual secara elektronik. Terdapat dua jenis saluran pemasaran online: jasa online komersial dan internet. Jasa online komersial (commercial online services) menawarkan jasa informasi dan pemasaran online kepada pelanggan yang membayar iuran bulanan. Jasa online yang paling dikenal ialah America Online, Compus Serve, dan Prodigy. Jasa online ini memberikan pelanggan informasi (berita, perpustakaan, pendidikan, perjalanan, olahraga, acuan), hiburan (permainan), jasa belanja, kesempatan dialog (bulletin board, forum, chat boxes) dan e-mail.

Setelah tumbuh dengan cepat selama pertengahan 1990-an, jasa online komersial sekarang telah didahului oleh internet sebagai saluran pemasaran online 
utama. Malah, semua perusahaan jasa online sekarang menawarkan akses internet sebagai jasa utama. Walaupun masih dalam masa pertumbuhan, penggunaan internet dan pemasaran online sedang tumbuh sangan pesat. Hingga tahun 1998, 26 juta rumah tangga telah terlibat dengan web, lebih dari dua kali jumlah itu dua tahun kemudian, dengan 52 juta rumah tangga diharapkan akan terhubung secara online pada 2000. Belanja konsumen pada web diharapkan melesat dari nol pada 1994 dan \$1,2 miliar pada 1996 hingga \$7,3 miliar hingga 2000. Penggunaaan internet bertambah pada laju 12.000 pengguna baru setiap hari, dan sejumlah analisis memprakirakan bahwa akan ada lebih dari satu miliar pengguna hingga 2000. Sekarang terdapat sebanyak 4 hingga 6 juta situs web di seluruh dunia, dan angka itu sedang tumbuh sebanyak 400 situs baru setiap pekan.

Ledakan pengguna internet telah menggembar-gemborkan menyingsing dunia baru perdagangan elektronik. Perdagangan elektronik (electronic commerce) merupakan istilah umum untuk proses pembelian dan penjualan yang didukung oleh cara-cara yang elektronik. Pasar elektronik merupakan "runag pasar" yang didalamnya penjual menawarkan produk dan jasanya secara elektronik, dan pembeli mencari informasi, mengidentifikasi apa yang mereka inginkan, dan memesan menggunakan kartu kredit atau cara pembayaran lain yang dapat dilakukan secara elektronik (Kotler \& Armstrong, 2001:256-257).

Pelayanan online menjadi begitu populer pemasaran online menghasilkan manfaat pada konsumen maupun pemasar

1. Manfaat untuk komsumen

Pembelian online memberi konsumen manfaat dasar yang sama dengan bentuk pemasaran langsung lainnya. Pembelian online itu nyaman: pelanggan tidak perlu bergelut dengan lalu lintas, mencari tempat parkir, dan berjalan dari toko-ke-toko dan lorong-ke-lorong yang tampaknya tak terbilang untuk mencari dan memeriksa produk. Mereka dapat membandingkan merek, memeriksa harga, dan memesan barang dagangan 24 jam sehari dari mana saja. Pemebelian online itu mudah dan pribadi: pelanggan menemui lebih sedikit percekcokan sewaktu membeli dan tidak harus menghadapi wiraniaga atau memberi kesempatan untuk dibujuk dan jual kecap emosi. Pemebelian online menawarkan kepada konsumen beberapa keunggulan tambahan. Jasa online komersial dan internet memberi konsumen akses informasi perbandingan yang melimpah, informasi tentang perusahaan, produk, dan pesaing. Disamping itu, pembelian online itu interaktif dan segera.

2. Manfaat untuk pemasar

a. pemasaran online juga menghasilkan manfaat untuk pemasar. Karena sifatnya yang satu-lawan-satu dan interaktif, pemasaran online merupakan alat yang bagus untuk pembangunan hubungan pelanggan;

b. pemasaran online dapat mengurangi biaya dan meningkatkan efesiensi;

c. Pemasaran online juga menawarkan keluwesan yang baik, yang membuat pemasar dapat membuat penyesuaian yang berkelanjutan pada tawaran dan programnya. (Kotler \& Armstrong, 2001:256-257).

Pengalaman online menjadi lebih kolaboratif dan terpusat pada pengguna memiicu lahirnya situs-situs jejearing sosial, blog gratis dan aplikasi yang 
memungkinkan pelanggan untuk menmberikan komentar pada materi digital. Jejaring sosial digital pun datang dan mengubah lagi semuanya dengan menambah dimensi baru dari evolusi keterlibatan dan pengaruh. Kedatangan jaringan peer-topeer yang sebenarnya dimana pengguna dapat memmbuat dan membaggi materi sekehendak mereka. Sampai hadirnya media sosial, pemasaran dari mulut kemulut tidak memiliki efek yang begitu bagus jadi media sosial mengambil proses dari mulut ke mulut biasa dan melipatgandakan kecepatan dan jangkauannya.

\section{6) Media Sosial Sebagai Sarana Promosi}

Media sosial menciptakan pengaruh dan skala dengan cara yang tidak dapat dilakukan oleh media tradisonal. Lebih baik lagi, media sosial melakukannya hanya dengan sepersekian biaya yang dihabiskan media tradisional (Blanchard, 2015:11-13).

Media sosial merupakan alat komunikasi, sepereti telepon dan email, yang mendukung tujuan fugsi bisnis penting, termasuk didalamnya hubungan masyarakat, pemasaran, pembangkitan minat pelanggan, layanan pelanggan, dan riset pasar(Blanchard, 2015:11-13).

Berbisnis online menggunakan media sosial/jejaring sosial bisa dibilang efektif dan efesien. Media sosial telah bisa digunakan oleh banyak orang dan mereka yang mengakses media sosial setiap hari pun lebih banyak dari pada mereka yang mengakses sebuah website.

Dalam penggunaannya ada tiga fungsi dalam perdagangan yang dapat dengan mudah ditingaktkan dengan program media sosial yaitu:

1. Media sosial dapat digunakan untuk meningkatkan penjualan;

2. Media sosial dapat digunakan untuk mendapatkan dukungan dari pelanggan;

3. Media sosial dapat dengan mudah digunakan untuk berhubungan dengan masyarakat (Blanchard, 2015:11-13).

Beberapa media sosisal yang banyak digunakan untuk berbisnis online/pemasaran online antara lain:

1. Facebook

Facebook adalah media sosial dengan penggguna paling banyak di dunia. Facebook memiliki iklan komersial berupa Facebook Ads yang bisa mendongkrak jumlah liker sebuah Fanpage. Facebook Fanpage adalah salah satu fitur yang paling sering digunakan oleh penjual online memasarkan produknya (Nisrina, 2015:128-131).

2. Instagram

Isntagram sendiri mamsih merupakan bagian dari Facebook yang memungkinkan teman Facebook memfolow akun Instgram kita. Makin populernya Instgram sebagai aplikasi yang digunakan untuk membagi foto membuat banyak pengguna yang terjun ke bisnis online turut mempromosika produk-produknya lewat Instagram (Nisrina, 2015:128-137).

3. Pinterest

Jejaring sisial ini sebenarnya hampir sama dengan Instagram, karena samasama mengekspose postingan dengan foto. Penggunaan Pinterest yang 
makin banyak di Indonesia membuat pembisnis online menggunakan wadah ini untuk berjualan. Pinterest mempunyai sistem board untuk mengkategorikan produk atau jasa yang ditawarkan.

4. Twitter

Timeline Twitter dalam satu menit atau beberapa menit bisa berganti dengan cepat, apalagi jika kita mengikuti banyak follower yang kerak membuat kicauan. Meski terbatas pada jumlah karakter, Twitter berguna juga untuk pemasaran produk secara online. Terutama sekali bagi akun yang telah memiliki jumlah follower banyak, media ini akan bermanfaat untuk promosi (Nisrina, 2015:140-141).

5. Blackberry Messenger

$B B M$ adalah sebuah aplikasi chating yang semula hanya terdapat dalam telepon genggam Blackberry. Namun semenjak tahun 2013 silam, Tak hanya aplikasi chatting semata, pengguna BBM dapat mengunggah foto atau status sesuai dengan keinginan mereka. Blackberry Massenger kini digunakan oleh oleh banyak pelaku bisnis online untuk mempromosikan produknya di dunia maya karena banyaknya pengguna Blackberry Messenger di Indonesia (Nisrina, 2015:143).

\section{ANALISIS DATA}

\section{Pasar Sudimampir Banjarmasin}

Pasar Sudimampir terletak di pusat Kota Banjarmasin, Pasar ini selain menjaul eceran, merupakan pusat grosir terbesar di Banjarmasin, sudah sejak lama ada dan dikenal oleh banyak orang. Di sini, Anda bisa berbelanja banyak keperluan seperti baju dari baju anak-anak hingga dewasa, perlengkapan muslim, perlengkapan umrah, keperluan rumah tangga seperti gelas, piring, gorden, taplak meja dan karpet. Lalu ada lagi tas, dompet, handuk, sepatu, sandal, kaus kaki, mainan anak, berbagai pernak-pernik oleh-oleh khas Timur Tengah seperti peralatan makan dan minum, kurma, kismis, pakaian dalam, kembang hingga kuekue jajanan khas Banjar seperti kakicak, jaring atau jengkol dan kue bingka. Harga yang ditawarkan pun beragam dari yang murah hingga mahal.

Secara geografis, Pasar Sudimampir berdekatan bahkan berbatasan dengan Sungai Martapura. Di masa lalu, Sungai Martapura menjadi penghubung para saudagar dan pedagang seantero Kalsel dan Kalteng. Tepian Sungai Martapura di dekat Pasar Sudimampir menjadi tempat tambatan kapal-kapal saudagar dari berbagai wilayah di Kalsel dan Kalteng. Di tepian sungai itulah, mereka melakukan bongkar muat barang yang dibeli dari Pasar Sudimampir. Walaupun sekarang sudah bisa menggunakan transportasi darat, perjalanan dari pelosok menuju ke Pasar Sudimampir melalui jalur sungai masih tetap dilakukan.

\section{Manfaat Media Sosial Sebagai Sarana Promosi Pada Pedagang Pakaian di Pasar Sudimampir Banjarmasin}

Dalam perdagangan kita pasti tahu dengan yang namanya pemasaran, menurut Kotler mengemukakan difinisi pemasaran adalah kegiatan manusia yang diarahkan pada usaha untuk memuaskan keinginan dan kebutuhan malaui proses 
pertukaran (Swastha, 1999:5). Seperti pengertian diatas di pasar Sudimampir Banjarmasin melakukan kegiatan pemasaran dimana terjadinya tukar-menukar antara konsumen dengan pedagang demi untuk memenuhi kebutuhan mereka masing-masing.

Dalam teori yang ada pemasaran itu memiliki strategi pemasaran atau biasa disebut dengan bauran pemasaran yang mana strategi tersebut adalah langkahlangkah yang harus dijalankan untuk mencapai tujuan. Didalam pemanfaatan media sosial sebagai sarana promosi oleh pedagang pakaian di pasar Sudimampir Banjarmasin tidak lepas dari strategi pemasaran/bauran pemasaran ini yaitu:

a. Strategi lokasi dan distribusi

b. Strategi promosi

c. Strategi produk

d. Strategi harga

Strategi promosi ini memiliki empat bauran promosi tetapi pedagang pakaian di pasar Sudimampir Banjarmasin hanya menggunakan tiga dari bauran promosi tersebut yaitu:

1. Periklanan (advertising);

Dari informan yang ada semua menggunakan periklanan yaitu melakukan promosi menggunakan media sosial sebagai media untuk periklanannya, dari sekian banyak media sosial yang dapat digunakan sebagai media periklanan, namum dari hasil wawancara yang dilakukan terdapat tiga media sosial yang digunakan yaitu:

\section{a. BBM}

BBM oleh pedagang pakaian di pasar Sudimampir Banjarmasin digunakan lebih untuk media pemesanan. Dengan mengggunakan BBM sebagai media pemesanan mempermudah pelanggan karna tidak harus pergi kepasar untuk berbelanja. Dari 15 informan yang ada semua menggunakan BBM sebagai media promosinya yang fungsinya adalah untuk pemesanan.

b. Facebook

Facebook digunakan oleh pedagang untuk mengupload foto menegenai barang yang mereka jual, dan juga bisa digunakan untuk pemesanan seperti halnya BBM. Dari Hasil wawancara diketahui hanya satu dari 15 informan yang menggunakan Facebook sebagai media promosinya.

c. Instagram

Sedangkan media sosial instagram khusus digunakan oleh pedagang pakaian untuk upload foto mengenai produk yang tersedia, ini membuat pembeli atau calon pembeli bisa memilihmilih mengenai barang yang ingin mereka beli. Hasil wawancara dengan informan diketahui ada tiga dari 15 informan yang menggunakan Isntagram sebagai media promosinya.

2. Promosi penjualan (sales promotion product);

Pedagang dipasar Sudimampir Banjarmasin menggunakan promosi penjualan dengan cara memberikan potongan harga kepada pelanggan tetap dan bagi pembeli yang berbelanja dengan jumlah tertentu. 
3. Penjualan pribadi (Personal Selling)

Semua informan yang ada juga melakukan penjualan pribadi dimana semua memiliki toko mereka masing-masing yang berada di pasar Sudimampir Banjarmasin yang dijaga oleh mereka sendiri selaku pemilik toko ataupun orang lain selaku karyawan yang mereka tugaskan untuk menjaga toko tersebut untuk melayani pelanggan yang datang.

Pemanfaatan media sosial oleh pedagang pakaian di pasar Sudimampir Banjarmasin sudah bagus bisa dilihat dari hasil wawancara dengan Informan yang menggunakan media sosisal sebagai sarana promosi dari segi penghasilan setiap bulannya semua mengalami peningkatan setelah mengggunakan media sosisal sebagai sarana promosi. Media sosial yang digunakan adalah Facebook, Istagram, dan BBM. Dapat disimpulkan bahwa pemanfaatan media sosial oleh pedagang pakaian di pasar Sudimampir dapat meningkatkan penjualan sesuai dengan fungsi media sosial dalam perdagangan yaitu dapat meningkatkan penjualan.

Sedangkan untuk strategi pemasaran syariah yang dijalankan oleh informan ada empat yaitu: Pertama: Shiddiq (benar dan jujur), jika seorang pengusaha senantiasa berperilaku benar dan jujur dalam sepanjang kegiatannya, jika seorang pemasar bersifat shiddiq haruslah menjiwai seluruh perilakunya dalam melakukan pemasaran, dalam berhubungan dengan pelanggan, dalam bertransaksi dengan nasabah, dan dalam membuat perjanjian dengan mitra bisnisnya (Kartajaya \& Sula, 2006:160). Kedua: Amanah (terpercaya, kredibel), artinya, dapat dipercaya, bertanggung jawab, dan kredibel, juga bermakna keinginan untuk memenuhi sesuatu sesuai dengan ketentuan. Diantara nilai yang terkait dengan kejujuran dan melengkapinya adalah amanah (Kartajaya \& Sula, 2006:165). Ketiga: Fathanah (cerdas), dapat diartikan sebagai intelektual, kecerdikan atau kebijaksanaan (Kartajaya \& Sula, 2006:168). Keempat: Tablig (komunikatif), artinya komunikatif dan argumentatif dengan tutur kata yang tepat dan mudah dipahami. Dalam bisnis, haruslah menjadi seorang yang mampu mengomunikasikan visi dan misinya dengan benar kepada karyawan dan stakeholder lainnya (Kartajaya \& Sula, 2006:171-172)

Table 1. Sosial media sarana promosi pada pedagang pakaian di pasar Sudimampir Banjarmasin

\begin{tabular}{|c|c|c|c|}
\hline $\begin{array}{c}\text { Jumlah Informan } \\
\text { penelitian }\end{array}$ & Tujuan & $\begin{array}{c}\text { Media } \\
\text { Pemasaran }\end{array}$ & Pemanfaatan media sosial \\
\hline 15 orang & \begin{tabular}{ll}
\multicolumn{2}{l}{ Mengupload } \\
foto, Video \\
mengenai \\
barang yang \\
jual.
\end{tabular} & $\begin{array}{l}\text { WA (Whats Up) } \\
\text { BBM (Blackberry } \\
\text { Messenger) FB } \\
\text { (Facebook, } \\
\text { Instagram. }\end{array}$ & $\begin{array}{l}\text { Sarana promosi yang dilakukan } \\
\text { oleh pedagang pakaian memberikan } \\
\text { dampak positif yaitu penjualan } \\
\text { mereka mengalami peningkatan } \\
\text { dimana sesuai dengan fungsi media } \\
\text { sosial dalam perdagangan yaitu } \\
\text { dapat meningkatkan penjualan. }\end{array}$ \\
\hline
\end{tabular}




\section{KESIMPULAN}

Berdasarkan uraian yang dipaparkan pada penyajian dan analisis data sebelumnya maka penulis mengambil simpulan bahwa:

Pemanfaatan media sosial sebagai sarana promosi pada pedagang pakaian dipasar Sudimampir Banjarmasin adalah dengan menggunakan BBM, Facebook, Instagram sebagai media promosinya yang mana fungsinya adalah sebagai media pemesanan dan mengenalkan produk mereka dengan cara memasang/mengupload foto melalui media sosial supaya memudahkan pelanggan dalam memilih produk. Pemanfaatan media sosial yang digunakan pedagang di pasar sudimampir ini dapat meningkatkan penjualan dimana sesuai dengan fungsi media sosial dalam perdagangan yaitu dapat meningkatkan penjualan.

\section{SARAN}

Sebagai penutup dari uraian, penulis ingin menyampaikan beberapa saran sebagai berikut:

1. Kepada pedagang di pasar Sudimampir Banjarmasin agar bisa lebih fokus menggunakan media sosialnya sebagai media promosi dengan cara menambah karyawan untuk menangani respon dimedia sosial atau memfokuskan karyawan untuk mempromosikan menggunakan media sosial.

2. Bagi pedagang lain dipasar Sudimampir Banjarmasin atau pedagang di tempat lain. 


\section{DAFTAR PUSTAKA}

Abdullah, Ma'ruf. 2011. Wirausaha Berbasis Syariah. Banjarmasin: Antasari. Press.

Afifuddin \& Beni, Ahmad Saebani. 2009. Metode Penelitian Kualitatif. Bandung: Pustaka Setia.

Agustin, Risa 2005. Kamus Lengkap Bahasa Indonesia. Surabaya: Serba Jaya.

Antonio, Muhammad Syafi'i. 2001. Bank Syariah dari Teori ke Praktik. Jakarta: Gema Insani.

Bearden, Ingram \& LaForge. 2004. Marketing, Principles and Perspectives. United States: Library of Congress Cataloging.

Bearden, William O. Thomas N. Ingram, \& Raymond W. LaForge.2004. Marketing Principles \& Perspectives. New York: McGraw-Hill/irwin.

Blanchard, Olivier. 2015. Sosial Media ROI. Jakarta: PT. Elex Media Komputindo.

Cannon, Joseph P. 2009 Pemasaran Dasar. Jakarta: Salemba Empat.

Cravens, David W. 2002. Pemasaran Strategis Jilid 2. Jakarta: PT. Gelora Aksara Pratama.

Departemen Agama Republik Indonesia. 2010 Al-Qur'an dan Terjemahannya. Semarang: AsySyifa.

Forsyth, Patrick. 2009. Marketing A Guide To The Fundamentals. New York: Bloomberg Press.

Husein, Umar. 2011. Metode Penelitian untuk Skripsi dan Tesis Bisnis. Jakarta: Rajawali Pers.

Kartajaya, Hermawan, \& Muhammad, Syakir Sula. 2006. Syariah Marketing. Bandung: PT Mizan Pustaka.

Kasmir. 2010. Kewirausahaan. Jakarta: PT Rajagrafindo Persada.

Kasmir. 2016. kewirausahaan. Jakarta: PT RajaGrafindo Persada.

Keegan, Warren J. 1996. Manajemen Pemasaran Global. Jakarta: Prenhallindo.

Kotler \& Armstrong. 2001. Prinsip-Prinsip Pemasaran. Jakarta: Penerbit Erlangga.

Kotler, Philip \& Kevin, Lane Keller. 2008 Manajemen Pemasaran Edisi 2. Indonesia: PT. Jaya Cemerlang.

Lubis, Suhrawardi. K. 2000 Hukum Ekonomi Islam. Jakarta: Sinar Grafindo.

Nisrina, M. 2015. Bisnis Online Manfaat Media Sosial Dalam Meraup Uang. Yogyakarta. KOBIS.

Perreault, William D E. Jerome Mc Charthy.2002. Basic Marketing A Global Managerial Approach. New York: Mc. Graw-Hill Compania.

Rahmadi. 2011. Pengantar Metode Penelitian. Banjarmasin: Antasari Press.

Sayuti, Jalaluddin A. 2015. Pengantar Bisnis Dalam Persfektif Aktivitas dan Kelembagaan. Bandung: Alfabeta.

Shimp, Terence A. 2003. Periklanan Promosi. Jakarta: Penerbit Erlangga.

Subagyo, P. J. 1999. Metode Penelitian dalam Teori dan Praktek. Jakarta: Rineka Cipta.

Subagyo, P. J. 2004 Metode Penelitian Dalam Teori dan Praktek. Jakarta: Rineka Cipta. 
Swastha, D.H. \& Basu. 1999. Azaz-Azaz Marketing. Yogyakarta: Liberty Yogyakarta.

Thompson, Arthur A. 2004. Strategy: Winning in The Marketplace. New York: McGraw-Hill/irwin. 